\title{
Liberation through the Acceptance of Nature and Technology in Octavia Butler's Parable of the Sower
}

\author{
Melanie A. Marotta ${ }^{1}$
}

Contained within Octavia Butler's Parable of the Sower (1993) is the message that technology permits a false sense of freedom. Butler creates characters that exist within chaotic technologically and monetarily motivated societies and, whether purposefully or not, the characters desire to escape. When used alone technology does not provide the means for protection and survival, but when utilized with nature the result is the preservation of human life. Through an examination of Lauren Oya Olamina's three communities it is clear that authentic liberation can only be achieved through a symbiotic relationship between technology and nature. Only Lauren's character realizes early in the novel that change is crucial to the continued existence of humanity, and her journey to Bankole's land gives her the means to pass her knowledge on to others. [Article copies available for a fee from The Transformative Studies Institute. E-mail address:_journal@transformativestudies.org Website: http://www.transformativestudies.org (C2010 by The Transformative Studies Institute. All rights reserved.]

KEYWORDS: Octavia E. Butler, Nature, Technology, Community, Liberation.

Donna J. Haraway in her work, "A Cyborg Manifesto: Science, Technology, and Socialist-Feminism in the Late Twentieth Century" defines a "cyborg" as "a hybrid of machine and organism, a creature of social real-

\footnotetext{
${ }^{1}$ Melanie A. Marotta is a doctoral candidate and Teaching Assistant in the Department of English and Language Arts at Morgan State University. She received her M.A. in English at Northwest Missouri State University in 2005. In 2003, Marotta received her B.A. from the University of Guelph. Marotta is currently working on her dissertation, which examines a selection of works by Toni Cade Bambara, Gayl Jones, and Toni Morrison. Address correspondence to: Melanie A. Marotta; e-mail: mmarotta9@gmail.com.
} 